\title{
GERONTOLOGY AND GERIATRICS
}

\author{
UDC 616-053.9
}

\section{Prevalence of vitamin D deficiency in elderly people with sarcopenia in the north-west of Russia}

\author{
Yu.A.Safonova, E. G.Zotkin, G. M. Glazunova \\ North-Western State Medical University named after I.I. Mechnikov, \\ 41, ul. Kirochnaya, St. Petersburg, 191015, Russian Federation
}

For citation: Safonova Yu. A., Zotkin E. G., Glazunova G. M. Prevalence of vitamin D deficiency in elderly people with sarcopenia in the north-west of Russia. Vestnik of Saint Petersburg University. Medicine, 2019, vol. 14, issue 1, pp. 58-68. https://doi.org/10.21638/11701/spbu10.2019.107

Vitamin D deficiency is quite common and highly prevalent in some regions of the world, seriously compromising quality of elderly people life. Optimal vitamin D level in serum is associated with stronger muscles and indicates additional 4-11\% improvement of muscular performance and $17 \%$ risk reduction of elderly people falls. Increased risk of falls due to sarcopenia is strongly associated with such undesirable health outcomes as disability, institutionalization, and eventually death. This study analyzes vitamin D status in 69 elderly people with sarcopenia among 230 patricipants (96.5\% of women, mean age of $74.1 \pm 6.5$ years), equaling to $30 \%$ ( $8.7 \%$ in men, $91.3 \%$ in women) prevalence in this age group. For evaluation of sarcopenia level, EWGSOP criteria were used. Muscle strength was assessed by a handheld dynamometer and muscle functioning was evaluated by SPPB-tests (walking speed, Five-TimesSit-to-Stand-Test and standing balance). Insufficient vitamin D supply was found in $97 \%$ of subjects with sarcopenia and $85.8 \%$ - without sarcopenia. Optimal vitamin D levels were identified only in $3 \%$ of sarcopenic subjects and $14.2 \%$ of non-sarcopenic ones with $\mathrm{p}<0.01$. Mean Vitamin $25(\mathrm{OH}) \mathrm{D}$ level in general population constituted $19.6 \pm 5.44 \mathrm{ng} / \mathrm{ml}$. Mean vitamin D level amog sarcopenic subjects aged 65-84 years constituted $18.2 \pm 3.04 \mathrm{ng} / \mathrm{ml}$, while among older individuals aged $85+$ years $-15.1 \pm 6.43 \mathrm{ng} / \mathrm{ml}, \mathrm{p}>0.05$. Histroy of falls within 12 months prior to the study was reported in $89.9 \%$ of patients with sarcopenia. Among them vitamin D deficiency was found in $60.3 \%$ (95\% CI: 53.0-67.4, $\chi^{2}=8.81$ with $\mathrm{p}=0.012$ ). $85.8 \%$ of individuals with vitamin $\mathrm{D}$ deficiency had low muscle strength $\left(\chi^{2}=174.61, \mathrm{p}<0.001\right)$. $60.4 \%$ of participants with sarcopenia and vitamin D deficiency had low total SPPB score (CI: 45.3-74.2, $\mathrm{p}<0.05$ ). Obtained data is indicative of high vitamin $\mathrm{D}$ deficiency prevalence. It was found out that Sarcopenia increases risk of vitamin D deficiency by 1.2 times (RR 1.2, $95 \%$ CI: $1.06-1.36, \mathrm{p}<0.01)$ in all studied age groups.

Keywords: vitamin D prevalence, vitamin D level, elderly, sarcopenia.

() Санкт-Петербургский государственный университет, 2019 


\section{Introduction}

High prevalence of vitamin D deficiency in different populations of different world regions was proved in numerous surveys [1-3]. Lack and deficiency of $25(\mathrm{OH}) \mathrm{D}$ appeared to be more common in older age groups [4], causing variety of symptoms and major health consequences in the most vulnerable elderly population [5-8]. Large number of investigations revealed strong correlation between vitamin D deficiency and increased risk of falls and fractures $[9 ; 10]$, but also associated with comorbide states, such as cardiovascular disceases, malignant neoplasms, neuropsychic disorders, infections, and autoimmune diseases [11-15]. Meta-analysis of cohort studies demonstrated beneficial effect of continuous vitamin D intake on reducing overall mortality, mostly among aged less 80 years [16; 17]. It was found out that serum levels of vitamin $25(\mathrm{OH}) \mathrm{D}$ less than $10 \mathrm{ng} / \mathrm{l}$ are associated with lower muscle strength due to sarcopenia, leading to balance disorders, falls and fractures in the elderly [5; 18-20].

Russia currently launched a few long-term studies to assess the prevalence of vitamin D deficiency in general population, with special focus on the age group $>65$ years [2123]. This report provides data from the populational study conducted in the North-West of Russia, as a part of Nationwide program, with a special focus on $25(\mathrm{OH}) \mathrm{D}$ deficiency in sarcopenic subjects aged $>65$ years.

\section{Materials and methods}

\subsection{Study of presented sampled participants}

All study participants were recruited from a geriatric doctor based on the following inclusion criteria: residents of the community, age $\geq 65$ years, adequate physical functioning and absence of any conditions compromising it; able to move around without walking aid, and absence of cognitive impairment based on total score ofr Mini mental state examination (MMSE).

Exclusion criteria were as follows: nursing home residence, use of hormone replacement and/or psychotropic drugs, cerebrovascular diseases, severe decompensated heart and renal diseases, non-controlled malignacies, neurological or psychiatric disorders, any kind of dizziness, blurred vision or lightheadedness when rising or standing for long time, indicative of orthostatic hypotension and/or vestibular disorders.

All the patients signed informed consent statement prior to inclusion into the study.

\subsection{Definitions of sarcopenia}

All 230 participants in the study were subjected to anthropometric evaluation (height and weight, body mass index - BMI). Following EWGSOP criteria, the diagnosis of sarcopenia was based on Dual Energy X-ray (DXA HOLOGIC Explorer QDR) measurement of skeletal muscle mass index (SMI) defined as appendicular skeletal mass/ height ${ }^{2}\left(\mathrm{~kg} / \mathrm{m}^{2}\right)$. Handgrip strength was evaluated by handheld dynamometer (HDD), and muscle function was assessed using Short Physical Performance Battery (SPPB) tests (evaluating balance, gait, side-by-side together in semi-tandem and tandem positions, time to walk 4 meters to pass at the usual speed and time to rise from a chair and return to the seated position five times). 


\subsection{Assessment blood samples}

Blood samples were collected in cold weather conditions (from September to May) from 179 patients, and serum was stored at $-70^{\circ} \mathrm{C}$. Serum 25 -hydroxyvitamin $\mathrm{D}(25(\mathrm{OH})$ D) was mesured using chemiluminescent immunoassay, ng/ml (Abbott Architect, USA). Vitamin D and Calcium intake was forbidden within 12 months prior to enrolment.

Vitamin D status was evaluated in accordance with Endocrine society criteria (ENDO, 2011) [26], which are also used by Cetral European Endocrine associations [27]. Vitamin $\mathrm{D}$ deficit was diagnosed at $25(\mathrm{OH}) \mathrm{D}$ level in serum less than $20 \mathrm{ng} / \mathrm{mL}$, insufficiency of vitamin D - at level equal 20-29 ng/mL, and sufficiency of vitamin D - at level over $30 \mathrm{ng} / \mathrm{mL}$.

\subsection{Statistic analysis}

Skeletal muscle mass index cut off values $<5.45 \mathrm{~kg} / \mathrm{m}^{2}$ for women and $<7.26 \mathrm{~kg} / \mathrm{m}^{2}$ for men were used for establishing the clinical diagnosis of sarcopenia. Handgrip strength was evaluated by using handheld dynamometer (HDD). The test values were considered low based on thresholds $<20 \mathrm{~kg}$ for women, and $<30 \mathrm{~kg}$ for men. Muscle function was assessed using Short Physical Performance Battery (SPPB) tests (evaluating balance, gait, strength and endurance by examining an individual's ability to stand with the feet sideby-side together in semi-tandem and tandem positions, time to walk 4 meters to pass at the usual speed and time to rise from a chair and return to the seated position five times). The SPPB test total score was calculated by summarizing individual scores per task using a standardized 0 to 12 scale. The total SPPB score $\leq 9$ was considered low. Vitamin D status was assessed according to the Endocrine Society criteria (ENDO, 2011) [26], which are also used by the Central European Endocrinology Associations [27]. Vitamin D deficiency was diagnosed at serum $25(\mathrm{OH}) \mathrm{D}$ levels $<20 \mathrm{ng} / \mathrm{ml}$, insufficiency $-20-29 \mathrm{ng} / \mathrm{ml}$ levels, and sufficiency $\geq 30 \mathrm{ng} / \mathrm{ml}$.

The level of significance was $5 \%(\mathrm{p}<0.05)$ and all the analyses were conducted using soft ware STATISTICA for Windows (version 10 of BXXR310F964808FA-V). All the data were presented as mean value \pm standard deviation (SD). Comparison of frequency distributions of qualitative variables was assessed by nonparametric $\mathrm{c} 2$ test. Comparison of quantitarive variables was performed using ANOVA. Pearson correlation was used to find the correlation between analysed variables.

\section{Results}

\subsection{Original Patient Characteristics}

230 patients aged $>65$ years ( 222 women $-96.5 \%$ and 8 men $-3.5 \%$ ), mean age $74.1 \pm 6.5$ years, living at latitude northern $59^{\circ}$ and at Eastern longitude $35^{\circ}$. Based on the sarcopenia status all participants were divided into two major groups: sarcopenic older adults $(n=69)$ and non-sarcopenic older adults $(n=161)$. The total study population was broken into 3 age groups: A-group include people aged 65-74 years, group B - 7584 years, group $\mathrm{C}-$ patients older than 85 years. Analysis of studied population revealed, that sarcopenia prevalence increases with patients age and at the age 85 years and older were revealed rather frequently $(\mathrm{p}<0.01)$. Obesity and metabolic syndrome are seldom revealed with statistical significance among patients with sarcopenia $(\mathrm{p}<0.0001)$. Male 
gender possesses increased risk of sarcopenia $(p=0.01)$. It is natural, that prevalence of sarcopenia increases with age, with the number of sarcopenic individuals prevailing the number of non-sarcopenic in group $\mathrm{C}(\mathrm{p}<0.01)$. Low and normal BMI values increase the risk of sarcopenia $(p<0.0001)$. Individuals from both - sarcopenic and non-sarcopenic groups - had similar educational levels, living standards, smoking status, and disability status (Table 1).

Table 1. Characteristics of studied group

\begin{tabular}{|c|c|c|c|}
\hline Characteristics & $\begin{array}{l}\text { Sarcopenic older adults } \\
\qquad(\mathrm{n}=69)\end{array}$ & $\begin{array}{l}\text { Non-sarcopenic older } \\
\text { adults }(\mathrm{n}=161)\end{array}$ & $P$-value \\
\hline Age,years [mean $( \pm S D)]$ & $75.9(6.8)$ & $73.1(6.1)$ & 0.0023 \\
\hline $65-74$ y $[\mathrm{n}(\%)]$ & $24(34.8)$ & $88(54.7)$ & 0.0057 \\
\hline $75-84$ y & $36(52.2)$ & $65(40.4)$ & 0.098 \\
\hline$\geq 85 y$ & $9(13.0)$ & $8(5.0)$ & 0.032 \\
\hline \multicolumn{4}{|l|}{$\operatorname{Sex}[\mathrm{n}(\%)]$} \\
\hline $\begin{array}{l}\text { Women } \\
\text { Men }\end{array}$ & $\begin{array}{c}63(91.3) \\
6(8.7)\end{array}$ & $\begin{array}{l}159(98.8) \\
2(1.2)\end{array}$ & 0.010 \\
\hline Disability & $50(72.5)$ & $117(72.7)$ & 0.97 \\
\hline Single-living people & $29(42.0)$ & $73(45.3)$ & 0.64 \\
\hline \multicolumn{4}{|l|}{ Smoking status [n (\%)] } \\
\hline Never & $65(94.2)$ & $157(97.5)$ & \multirow{2}{*}{0.25} \\
\hline Former & $4(5.8)$ & $4(2.5)$ & \\
\hline $\begin{array}{l}\text { Prevalent disease }[\mathrm{n}(\%)] \\
\text { Cardiovascular disease } \\
\text { Metabolic syndrome } \\
\text { Obesity } \\
\text { Chronic Obstructive Pulmonary Diseases } \\
\text { Diabetes }\end{array}$ & $\begin{array}{l}50(72.5) \\
6(8.7) \\
2(2.9) \\
4(5.8) \\
4(5.8)\end{array}$ & $\begin{array}{l}121(75.2) \\
80(49.7) \\
65(40.4) \\
13(8.1) \\
16(9.9)\end{array}$ & $\begin{aligned} & 0.69 \\
< & 0.0001 \\
< & 0.0001 \\
& 0.54 \\
& 0.31\end{aligned}$ \\
\hline
\end{tabular}

\subsection{Vitamin D provision}

Serum vitamin $25(\mathrm{OH})$ D levels were measured for 179 patients (66 with sarcopenia and 113 without sarcopenia) among 230 elderly patients. Measured vitamin $25(\mathrm{OH}) \mathrm{D}$ concentration varied from 2.3 to $70.5 \mathrm{ng} / \mathrm{mL}$. Mean $( \pm \mathrm{SD})$ vitamin D level constituted $19.6 \pm 5.44 \mathrm{ng} / \mathrm{ml}$ in studied samples of 179 patients, $17.8 \pm 8.6 \mathrm{ng} / \mathrm{ml}$ - in sarcopenic, and $20.7 \pm 5.44 \mathrm{ng} / \mathrm{ml}$ - in non-sarcopenic $(p=0.016)$. Therefore, based on the Endocrine Society criteria (ENDO, 2011) and Central European Guidelines [27], vitamin D deficiency was reveales in 60.3\% (95\% CI: 53,0-67,4, $\chi^{2}=8,81, p=0.012$ ), vitamin D insufficiency - in $29.6 \%$ and vitamin D sufficiency - in only $10.1 \%$ out of 179 examined patients (Table 2).

Optimal vitamin $25(\mathrm{OH})$ D level (vitamin D level $\geq 30 \mathrm{ng} / \mathrm{mL}$ ) was found only in $3 \%$ of sarcopenic patients and in $14.2 \%$ of non-sarcopenic ones.

Among 179 patient evaluated mean vitamin $25(\mathrm{OH}) \mathrm{D}$ levels in group A (aged 65 to 74 years; $\mathrm{n}=83: 80 \mathrm{~F} / 3 \mathrm{M}$ ) constituted $20.3 \pm 7.71 \mathrm{ng} / \mathrm{mL}$, in group $\mathrm{B}$ (aged 75 to 84 years; 
Table 2. Prevalence of vitamin D deficiency and insufficiency in the studied population and groups with and without sarcopenia

\begin{tabular}{|l|c|c|c|c|c|c|c|}
\hline \multirow{2}{*}{$\begin{array}{c}\text { Serum 25 (OH)D } \\
\text { levels }\end{array}$} & \multicolumn{2}{|c|}{$\begin{array}{c}\text { Sarcopenic older adults } \\
(\mathbf{n}=66)\end{array}$} & \multicolumn{2}{c|}{$\begin{array}{c}\text { Non-sarcopenic older } \\
\text { adults }(\mathbf{n}=113)\end{array}$} & \multicolumn{2}{|c|}{$\begin{array}{c}\text { Overall } \\
(\mathbf{n}=179)\end{array}$} & \multirow{2}{*}{$\mathbf{p}^{*}$} \\
\cline { 2 - 7 } & Abs.,(\%) & $95 \%$ CI & Abs.,(\%) & $95 \%$ CI & Abs.,(\%) & $95 \%$ CI & \\
\hline$<20 \mathrm{ng} / \mathrm{ml}$ & $48(72.7)$ & $61.2-82.9$ & $60(53.1)$ & $43.8-62.3$ & $108(60.3)$ & $53.0-67.4$ & \\
\hline 20 to $29 \mathrm{ng} / \mathrm{ml}$ & $16(24.2)$ & $14.6-35.4$ & $37(32.7)$ & $24.3-41.7$ & $53(29.6)$ & $23.1-36.5$ & \multirow{2}{*}{0.012} \\
\hline$\geq 30 \mathrm{ng} / \mathrm{ml}$ & $2(3.0)$ & $0.3-8.6$ & $16(14.2)$ & $8.3-21.2$ & $18(10.1)$ & $6.1-14.9$ & \\
\hline
\end{tabular}

* - Fisher's criterion.

$\mathrm{n}=85: 81 \mathrm{~F} / 4 \mathrm{M})-19.3 \pm 15.9 \mathrm{ng} / \mathrm{mL}$, in group $\mathrm{C}($ aged $>85$ years; $\mathrm{n}=11: 11 \mathrm{~F} / 0 \mathrm{M})-$ $16.7 \pm 6.43 \mathrm{ng} / \mathrm{mL}(p<0.05)$. Gender M/F differences in mean vitamin D levels in 3 analysed age groups were as follows: group A $-14.5 \pm 2.47 \mathrm{ng} / \mathrm{ml}$ vs $20.6 \pm 7.71 \mathrm{ng} / \mathrm{ml}$ $(p<0.01)$, and group $B-15.5 \pm 4.1 \mathrm{ng} / \mathrm{ml}$ vs $19.5 \pm 4.21 \mathrm{ng} / \mathrm{ml}(p<0.05)$.

Comparison of mean serum $25(\mathrm{OH})$ D levels in 3 age groups in relation to sarcopenia status is presented in Fig. 1.

Mean vitamin $25(\mathrm{OH}) \mathrm{D}$ values in group A in relation to sarcopenia were as follows: in subjects with sarcopenia $(\mathrm{n}=23: 21 \mathrm{~F} / 2 \mathrm{M}) 18.2 \pm 3.04 \mathrm{ng} / \mathrm{ml}$, and without sarcopenia $(\mathrm{n}=60: 59 \mathrm{~F} / 1 \mathrm{M})-21.1 \pm 1.63 \mathrm{ng} / \mathrm{ml}(p<0.05)$; in group B in sarcopenic subjects $(\mathrm{n}=35: 31 \mathrm{~F} / 4 \mathrm{M}) 17.9 \pm 1.45 \mathrm{ng} / \mathrm{ml}$, in non-sarcopenic $(\mathrm{n}=50: 50 \mathrm{~F} / 0 \mathrm{M})-20.2 \pm$ $1.63 \mathrm{ng} / \mathrm{ml}(p<0.01)$, in group $\mathrm{C}-\operatorname{sarcopenic}(\mathrm{n}=8: 8 \mathrm{~F} / 0 \mathrm{M})-15.1 \pm 1.63 \mathrm{ng} / \mathrm{ml}$, and non-sarcopenic $(\mathrm{n}=3: 3 \mathrm{~F} / 0 \mathrm{M})-20.9 \pm 1.23 \mathrm{ng} / \mathrm{ml}(p<0.01)$

Vitamin D deficiency was revealed among all men regardless of their sarcopenia status. As for female population, vitamin $25(\mathrm{OH})$ D deficiency $(<20 \mathrm{ng} / \mathrm{ml})$ was detected in $70 \%$ of patients with sarcopenia and $52.7 \%$ without sarcopenia, vitamin $25(\mathrm{OH}) \mathrm{D}$ insufficiency (20-29 $\mathrm{ng} / \mathrm{ml}$ ) was found in $26.7 \%$ sarcopenic females and $33 \%$ non-sarcopenic, while optimal vitamin $25(\mathrm{OH})$ D levels $(\geq 30 \mathrm{ng} / \mathrm{ml}$ ) present only in $3.3 \%$ of sarcopenic women and in $14.3 \%-$ non-sarcopenic $(p<0.01)$ (Fig. 2$)$.

\subsection{Vitamin D and skeletal muscles}

Analysis of skeletal muscle parameters was carried out in relation to vitamin $25(\mathrm{OH})$ D levels (see Table 3).

Multivariate analysis showed lower mean handgrip strength values in vitamin $\mathrm{D}$ deficient $(<20 \mathrm{ng} / \mathrm{mL}$ ) patients, equaling to $15.5 \pm 4.3 \mathrm{~kg}$, as compared to individuals with sufficient vitamin D levels $-22.6 \pm 4.7 \mathrm{~kg}(p<0.001)$. Mean gait speed in vitamin D deficient patients constituted $0.63 \pm 0.16 \mathrm{~m} / \mathrm{s}$, while in case of patients with sufficient vitamin D level $-0.84 \pm 0.12 \mathrm{~m} / \mathrm{s}$. SPPB mean score in vitamin D deficient cases was $7.1 \pm$ 2.4 points, and in case of vitamin D sufficient patients $-10.1 \pm 1.6$ points. $85.8 \%$ patients with vitamin $\mathrm{D}$ deficit had low handgrip strength $\left(\chi^{2}=174.61, p<0.001\right)$. And $60.4 \%$ of participants with sarcopenia and vitamin D deficit had low total SPPB score (95\% CI: 45.3-74.2, $p<0.05)$. 


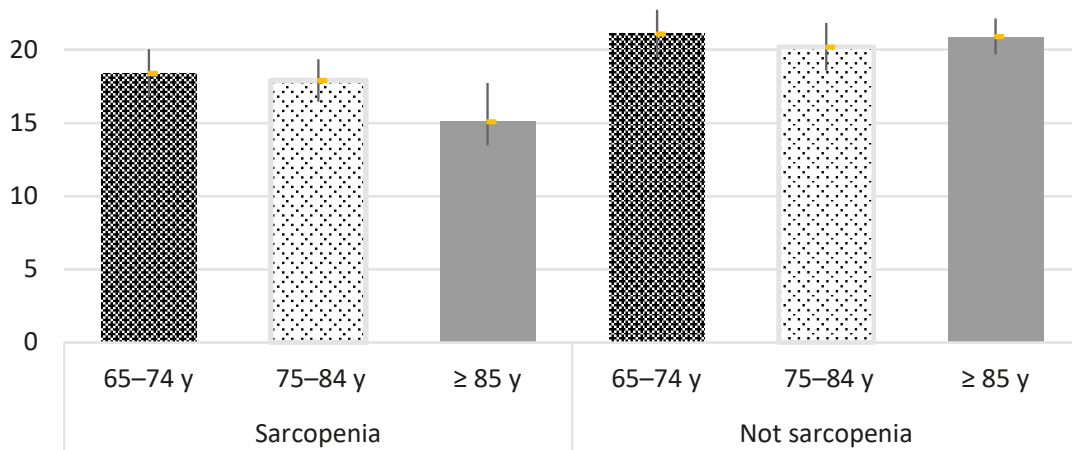

Fig. 1. Mean serum $25(\mathrm{OH}) \mathrm{D}$ levels in sarcopenic and non-sarcopenic patients in 3 studied age groups.

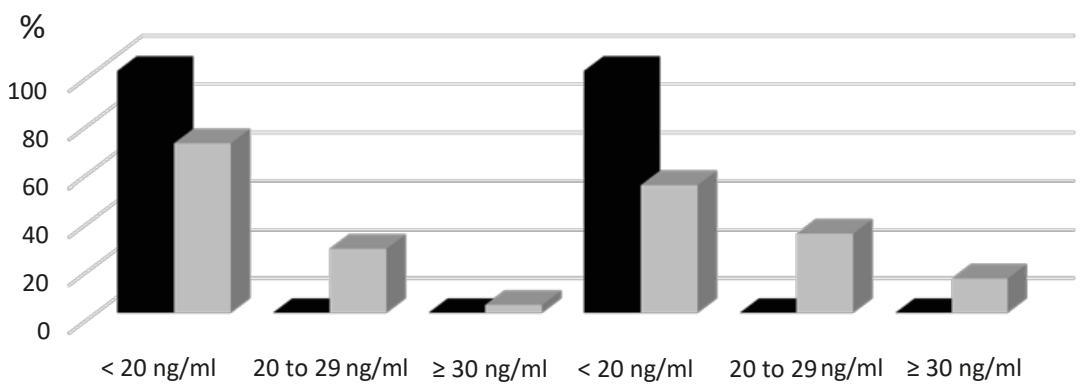

Sarcopenic older adults

Non-sarcopenic older adults

Men Women

Fig. 2. Prevalence of vitamin D deficiency and its insufficiency in performed study among men and women with and without sarcopenia.

Table 3. Correlation of serum 25(OH)D level with skeletal muscles parameters

\begin{tabular}{|c|c|c|c|c|c|c|c|c|c|}
\hline \multirow{2}{*}{ Parameters } & \multicolumn{3}{|c|}{$\begin{array}{l}\text { Serum } 25(\mathrm{OH}) \text { D levels, } \\
\text { ng/ml, Me [Q1; Q3] }\end{array}$} & \multicolumn{6}{|c|}{$\begin{array}{c}\text { Serum } 25 \text { (OH) D levels, } \mathrm{ng} / \mathrm{ml} \\
(\mathrm{M} \pm \sigma)\end{array}$} \\
\hline & $\begin{array}{c}\geq 30 \\
(\mathrm{n}=18)\end{array}$ & $\begin{array}{l}20 \text { to } 29 \\
(n=53)\end{array}$ & $\begin{array}{c}<20 \\
(\mathrm{n}=108)\end{array}$ & $\mathbf{p}^{\wedge}$ & $\begin{array}{c}\geq 30 \\
(\mathrm{n}=18)\end{array}$ & $\begin{array}{l}20 \text { to } 29 \\
(\mathrm{n}=53)\end{array}$ & $\begin{array}{c}<20 \\
(\mathrm{n}=108)\end{array}$ & $\begin{array}{c}\text { Overall } \\
(\mathrm{n}=230)\end{array}$ & $\mathrm{p}^{*}$ \\
\hline $\begin{array}{l}\text { Handgrip } \\
\text { strength, } \\
\text { kg }\end{array}$ & $\begin{array}{l}22.0 \\
{[20.0 ;} \\
25.0]\end{array}$ & $\begin{array}{l}18.0 \\
{[15.0 ;} \\
19.0]\end{array}$ & $\begin{array}{c}15.0 \\
{[13.0 ; 18.0]}\end{array}$ & $<0.001$ & $22.6 \pm 4.7$ & $17.0 \pm 3.9$ & $15.5 \pm 4.3$ & $17.0 \pm 4.8$ & $<0.001$ \\
\hline $\begin{array}{l}\text { Gait speed, } \\
\mathrm{m} / \mathrm{s}\end{array}$ & $\begin{array}{c}0.85 \\
{[0.80} \\
0.91]\end{array}$ & $\begin{array}{c}0.71 \\
{[0.61 ;} \\
0.80]\end{array}$ & $\begin{array}{c}0.64 \\
{[0.4 ; 0.76]}\end{array}$ & $<0.001$ & $0.84 \pm 0, .2$ & $0.70 \pm 0.18$ & $0.63 \pm 0.16$ & $0.69 \pm 0.18$ & $<0.001$ \\
\hline $\begin{array}{l}\text { SPPB } \\
\text { score, } \\
\text { point }\end{array}$ & $\begin{array}{c}10.0 \\
{[10.0} \\
11.0]\end{array}$ & $\begin{array}{c}9.0 \\
{[7.0 ;} \\
10.0]\end{array}$ & $\begin{array}{c}7.0 \\
{[6.0 ; 9.0]}\end{array}$ & $<0.001$ & $10.1 \pm 1.6$ & $8.0 \pm 2.6$ & $7.1 \pm 2.4$ & $7.8 \pm 2.6$ & $<0.001$ \\
\hline
\end{tabular}

$\wedge$ - Mann-Whitney U test; * - Welch test. 


\section{Discussion}

Sarcopenia is a common clinical problem for people aged over 65 years, associated with many unfavorable outcomes [28]. The prevalence of sarcopenia varies widely, depending on specific population studied (such as community residents, or people living in nursing or care homes in respective environment, or different social and ethnic groups, or geography of residence, etc.) $[29 ; 30]$ and differences in the methods used to evaluate muscle mass, handgrip strength and physical performance. A number of factors are known to affect muscle strength and muscle function with aging, and the relationship between skeletal muscle health and vitamin $\mathrm{D}$ levels has been well documented in clinical studies [32; 33]. A wide range of muscle deficiencies associated with varying degrees of vitamin $\mathrm{D}$ deficiency has been described, as well as positive effects of vitamin $\mathrm{D}$ supplementation.

The study was aimed to determine prevalence of the patients with sarcopenia among residents at North-West of Russia. Sarcopenia was assessed following the EWGSOP guidelines; therefore the procedure included evaluation of the index of muscle mass, skeletal muscle strength and physical performance [24]. The prevalence of sarcopenia in the population assessed equaled to $30.0 \%$. According to the International Sarcopenia Initiative Report (ISI, 2014), the prevalence of sarcopenia varies significantly, with inevitable regional and age-related fluctuations, and achieveing 1-29\% levels - among community residents, $14-33 \%$ - in long-term care groups, and 10\% - in a single acute hospital care survey. These data were collected from eighteen documents that were finally selected by members of the ISI working group for inclusion into this review [30]. Prevalence of sarcopenia in the Russian northwestern cohort was higher, than in other countries. Presumably this difference can ne explained by some socio-economic (desolated single elderly people, monotonous diet, sedentiary life styles) and environmental factors (insufficient sunlight). A more sophisticated analysis produced quite expected results: higher prevalence of sarcopenia among elderly aged $85+$ years. Multiple studies confirmed increasing with age prevalence of sarcopenia [34;35]. Prevalence of sarcopenia among studied three age groups (A: 65-74, B: 75-84, C: 85 years and older), reached $21.4 \%, 35.6 \%$ and $52.9 \%$, respectively.

Clinical relationship between serum vitamin D concentrations and muscle strength/ physical characteristics was determined in many observational studies. In the Invecchiare in Chianti study (InCHIANTI) (966 individuals, 435 men and 531 women; mean age 75 years), significant correlation between low vitamin D levels and poor physical performance was established using a hand grip test and a short physical battery test. Physical performance of patients with serum vitamin $\mathrm{D}$ below $25 \mathrm{nmol} / \mathrm{L}$ was lower than in case of patients with vitamin level above $25 \mathrm{nmol} / \mathrm{L}$. The handgrip muscle strength based on obtained high presicion dynamometry data was also significantly higher in case of individuals with vitamin D levels above $50 \mathrm{nmol} / \mathrm{L}$ as compared to patients whose level was lower this threshold [36]. Mastaglia et al. reported higher lower limbs muscular strength of women over 65 years with vitamin D levels greater than $50 \mathrm{nmol} / \mathrm{L}$ [37]. A meta-analysis of seven studies showed that participants receiving low doses of vitamin D or placebo had baseline muscle strength between 3 and $23 \mathrm{~kg}$ [38]. In detailed analysis of data from the prospective study of Longitudinal Aging in Amsterdam (LASA) (1200 elderly men and women, 3 years follow up), Visser et al. showed that elderly people with low vitamin D levels $(<25 \mathrm{nmol} / \mathrm{L})$ had 2.5 -fold increased risk of sarcopenia, defined as a loss of more 
than $40 \%$ of the arm strength or loss of more than $3 \%$ muscle mass over a 3-year period compared to patients with vitamin D levels over $50 \mathrm{nmol} / \mathrm{L}$ [39]. Bischoff-Ferrari et al. in a survey of the US outpatient population aged $60-90$ years $(n=4100)$ showed that $25(\mathrm{OH}) \mathrm{D}$ concentrations between 40 and $94 \mathrm{nmol} / \mathrm{L}$ are associated with an improvement in the function of lower extremities musculoskeletal system, than concentrations $<40 \mathrm{nmol} / \mathrm{L}$ [40]. The older population is heterogeneous in age and related frailty due to varying prevalence of chronic diseases and types of treatment, and also with respect to dependence in daily life activities. Therefore, it can be expected, that studies envolving the elderly will yield in general mixed results unless the population is defined more accurately according to above mentioned factors. Moreover, the gender issue should be taken into account, as most studies recruited only or predominantly women.

Our results are consistent with many published reports, indicating strong sociation between vitamin $\mathrm{D}$ level and muscular status and performance. There's an obvious trend of deteriorating with age vitamin D deficiency/insufficiency, leaving only $10,1 \%$ of studied population with vitamin D sufficiency. This cross-sectional study established a direct association between vitamin D status and parameters of muscle strength and physical performance. Hence, handgrip strength, gait speed, and total SPPB score were significantly lower in subjects with serum $25(\mathrm{OH}) \mathrm{D}$ levels $<20 \mathrm{ng} / \mathrm{ml}$ as compared to individuals with normal vitamin D concentrations. Mean 25(OH)D levels were significantly lower among women with established sarcopenia vs subjects without sarcopenia in all age groups (65$75,76-85,>85$ years old): $18.2 \pm 3.04$ vs. $21.1 \pm 1.63 \mathrm{ng} / \mathrm{ml} ; 17.9 \pm 1.45$ vs. $20.2 \pm 1.63 \mathrm{ng} / \mathrm{ml}$, and $15.1 \pm 1.63$ vs. $20.9 \pm 1.23 \mathrm{ng} / \mathrm{ml}$ respectively.

\section{Conclusion}

Preliminary data from survey of elderly people living in the North-West region of the Russian Federation show close relationship between vitamin D status and musclular strength and function. Provided evidence indicate that vitamin D deficiency is associated with a decrease in muscle strength and function. Studies with sufficient sample size and more sophisticated analyses are needed to identify more precisely the prevalence and risk factors for sarcopenia.

Transparency declaration. The lead author affirms that this paper is an honest, accurate and transparent account of the study being reported, that no important aspects of the study have been omitted.

Acknowledgements: none.

Declarations of interest: none.

\section{Conflict of interest, source of funding and Authorship}

The authors declare that they have no conflicts of interest.

This research did not receive any specific grant from funding agencies in the public, commercial, or not-for-profit sectors.

\section{References}

1. Van Schoor N. M., Lips P. Worldwide vitamin D status. Best Practice \& Research Clinical Endocrinology \& Metabolism, 2011, vol.25, no. 4, pp.671-680. https://doi.org/10.1016/j.beem.2011.06.007 
2. Lips P. Vitamin D status and nutrition in Europe and Asia. The Journal of Steroid Biochemistry and Molecular Biology, 2007, vol. 103, no.3-5, pp.620-625. https://doi.org/10.1016/j.jsbmb.2006.12.076

3. Bruyère O., Slomian J., Beaudart C., Buckinx F., Cavalier E., Gillain S., Petermans J., Reginster J.Y. Prevalence of vitamin D inadequacy in European women aged over 80 years. Archives of Gerontology and Geriatrics, 2014, vol.59, no. 1, pp. 78-82. https://doi.org/10.1016/j.archger.2014.03.010

4. Holick M.F. Vitamin D deficiency. N. Engl. J. Med., 2007, vol.357, no.3, pp.266-281. https://doi. org/10.1056/nejmra070553

5. Wacker M., Holick M.F. Vitamin D - Effects on skeletal and extraskeletal health and the need for supplementation. Nutrients, 2013, vol.5, no. 1, pp.111-148. https://doi.org/10.3390/nu5010111

6. Gendelman O., Itzhaki D., Makarov S., Bennun M., Amital H. A randomized double-blind placebocontrolled study adding high dose vitamin $\mathrm{D}$ to analgesic regimens in patients with musculoskeletal pain. Lupus, 2015, vol.24, no.4-5, pp.483-489. https://doi.org/10.1177/0961203314558676

7. Heath K. M., Elovic E. P. Vitamin D deficiency-Implications in the rehabilitation setting. Am. J. Phys. Med. Rehab., 2006, vol. 85, no. 11, pp.916-923. https://doi.org/10.1097/01.phm.0000242622.23195.61

8. Shinchuk L., Holick M. F. Vitamin D and rehabilitation: Improving functional outcomes. Nutr. Clin. Pract., 2007, vol.22, no. 3, pp.297-304. https://doi.org/10.1177/0115426507022003297

9. The DIPART Group. Patient level pooled analysis of 68500 patients from seven major vitamin D fracture trials in US and Europe. BMJ, 2010, no.340, p.b5463. https://doi.org/10.1136/bmj.b5463

10. Bolland M. J., Grey A., Gamble G.D., Reid I. R. The effect of vitamin D supplementation on skeletal, vascular, or cancer outcomes: a trial sequential meta-analysis. Lancet Diab. Endocrinol., 2014, vol. 2, no. 4, pp. 307-320. https://doi.org/10.1016/s2213-8587(13)70212-2

11. Pourshahidi L.K. Vitamin D and obesity: current perspectives and future directions. Proceedings of the Nutrition Society, 2014, vol.74, no. 2, pp. 115-124. https://doi.org/10.1017/s0029665114001578

12. Antico A., Tampoia M., Tozzoli R., Bizzaro N. Can supplementation with vitamin D reduce the risk or modify the course of autoimmune diseases? A systematic review of the literature. Autoimmunity Reviews, 2012, vol.12, no. 2, pp. 127-136. https://doi.org/10.1016/j.autrev.2012.07.007

13. Seida J. C., Mitri J., Colmers I. N., Majumdar S. R., Davidson M.B., Edwards A.L., Hanley D. A., Pittas A.G., Tjosvold L., Johnson J.A. Effect of Vitamin D Supplementation on Improving Glucose Homeostasis and Preventing Diabetes: A Systematic Review and Meta-Analysis. J. Clin. Endocrinol. Metab., 2014, vol.99, no. 10, pp.3551-3560. https://doi.org/10.1210/jc.2014-2136

14. Souberbielle J.C., Body J.J., Lappe J. M., Plebani M., Shoenfeld Y., Wang T. J., Bischoff-Ferrari H. A., Cavalier E., Ebeling P. R., Fardellone P., Gandini S., Gruson D., Guérin A. P., Heickendorff L., Hollis B. W., Zittermann A. Vitamin D and musculoskeletal health, cardiovascular disease, autoimmunity and cancer: Recommendations for clinical practice. Autoimmunity Reviews, 2010, vol.9, no. 11, pp. 709-715. https://doi.org/10.1016/j.autrev.2010.06.009

15. Lavie C. J., Lee J.H., Milani R. V. Vitamin D and cardiovascular disease will it live up to its hype? J. Am. Coll. Cardiol., 2011, vol.58, no. 15, pp. 1547-1556. https://doi.org/10.1016/j.jacc.2011.07.008

16. Zheng Y., Zhu J., Zhou M., Cui L., Yao W., Liu Y. Meta-Analysis of Long-Term Vitamin D Supplementation on Overall Mortality. Meta-Analysis of Long-Term Vitamin D Supplementation on Overall Mortality. PLoS ONE, 2013, vol. 8, no. 12, p. e82109. https://doi.org/10.1371/journal.pone.0082109

17. Kalyani R. R., Stein B., Valiyil R., Manno R., Maynard J. W., Crews D. C. Vitamin D treatment for the prevention of falls in older adults: systematic review and meta-analysis. J. Am. Geriatr. Soc., 2010, vol. 58, no. 7, pp. 1299-1310. https://doi.org/10.1111/j.1532-5415.2010.02949.x

18. Bruyère O., Cavalier E., Souberbielle J. C., Bischoff-Ferrari H. A., Beaudart C., Buckinx F., Buckinx F., Reginster J. Y., Rizzoli R. Effects of vitamin D in the elderly population: current status and perspectives. Archives of Public Health, 2014, vol. 72, no. 1, p. 32. https://doi.org/10.1186/2049-3258-72-32

19. Bischoff-Ferrari H. A. Relevance of vitamin D in muscle health. Rev. Endocr. Metab. Disord, 2012, vol. 13, no. 1, pp. 71-77. https://doi.org/10.1007/s11154-011-9200-6

20. Beaudart C., Buckinx F., Rabenda V., Gillain S., Cavalier E., Slomian J., Petermans J., Reginster J.Y., Bruyère O. The Effects of Vitamin D on Skeletal Muscle Strength, Muscle Mass, and Muscle Power: A Systematic Review and Meta-Analysis of Randomized Controlled Trials. J. Clin. Endocrinol. Metab., 2014, vol.99, no. 11, pp.4336-4345. https://doi.org/10.1210/jc.2014-1742

21. Bakhtiiarova S., Lesnyak O., Kuznetsova N., Blankenstein M.A., Lips P. Vitamin D status among patients with hip fracture and elderly control subjects in Yekaterinburg, Russia. Osteoporoz. Int., 2006, vol. 17, no. 3, pp. 441-446. https://doi.org/10.1007/s00198-005-0006-9 (In Russian)

22. Karonova T. L., Grineva E. N., Nikitina I. L., Tsvetkova E. V., Todieva A. M., Beliaeva O. D., Mikheeva E. P., Globa P. Yu., Andreeva A. T., Beletskaia I. S., Omelchuk N. V., Fulonova L. S., Shlyakhto E. V. Prevalence of vitamin D deficiency in the North-West region of the Russian Federation among residents of St. 
Petersburg and Petrozavodsk. Osteoporoz i osteopatii, 2013, vol.16, no.3, pp.33-37. https://doi. org/10.14341/osteo201333-7 (In Russian)

23. Safonova Yu.A., Zotkin E. G., Glazunova G. M., Strukov E. L. Analysis of security by vitamin D of the elderly people. Adv. geront., 2018, vol.31, no. 2, pp. 184-190. (In Russian)

24. Cruz-Jentoft A.J., Baeyens J.P., Bauer J.M., Boirie Y., Cederholm T., Landi, F., Martin F.C, Michel J.-P., Rolland Y., Schneider S.M., Topinkova E., Vandewoude M., Zamboni M. Sarcopenia: European consensus on definition and diagnosis: Report of the European Working Group on Sarcopenia in Older People. Age and Ageing, 2010, vol.39, no. 4, pp.412-423. https://doi.org/10.1093/ ageing/afq034

25. Cruz-Jentoft A.J., Bahat G., Bauer J., Boirie Y., Bruyère O., Cederholm T., Cooper C., Landi, F., Rolland Y., Sayer A.A., Schneider S.M., Sieber C.C., Topinkova E., Vandewoude M., Visser M., Zamboni M. Sarcopenia: revised European consensus on definition and diagnosis. Age and Ageing, 2019, vol.48, no. 1, pp. 16-31. https://doi.org/10.1093/ageing/afy169

26. Holick M.F., Binkley N.C., Bischoff-Ferrari H.A., Gordon C.M., Hanley D.A., Heaney R.P., Heaney R. P., Hassan Murad M., Weaver C.M. Evaluation, treatment, and prevention of vitamin D deficiency: an endocrine society clinical practice guideline. J. Clin. Endocrinol. Metab., 2011, vol.96, no. 7, pp. 1911-1930. https://doi.org/10.1210/jc.2011-0385

27. Pludowski P., Karczmarewicz E., Bayer M., Carter G., Chlebna-Sokól D., Czech-Kowalska J., Dębski R., Decsi T., Dobrzańska A., Franek E., Głuszko P., Grant W.B., Holick M.F., Yankovskaya, Konstantynowicz J., Książyk J.B., Księżopolska-Orłowska K., Lewiński A., Litwin M., Lohner S., Lorenc R.S., Łukaszkiewicz J., Marcinowska-Suchowierska E., Milewicz A., Misiorowski W., Nowicki M., Povoroznyuk V., Rozentryt P., Rudenka E., Shoenfeld Y., Socha P., Solnica B., Szalecki M., Tałałaj M., Varbiro S., Żmijewski M. A. Practical guidelines for the supplementation of vitamin D and the treatment of deficits in Central Europe - reccomendation of vitamin D intakes in the general population and groups at risk of vitamin D deficiency. Endokrynol. Pol, 2013, vol.64, no. 4, pp.319-327. https://doi.org/10.5603/ep.2013.0012

28. Fielding R. A., Vellas B., Evans W. J., Bhasin S., Morley J. E., Newman A. B., Gabor van Kan A., Andrieu S., Bauer J., Breuille D., Cederholm T., Chandler J., C.De Meynard, Donini L., Harris T., Kannt A., Guibert F. K., Onder G., Papanicolaou D, Rolland Y., Rooks D., Sieber C., Souhami E., Verlaan S., Zamboni M. Prevalence, Etiology, and Consequences. International Working Group on Sarcopenia. Journal of the American Medical Directors Association, 2011, vol.12, no.4, pp.249-256. https://doi. org/10.1016/j.jamda.2011.01.003

29. Iannuzzi-Sucich M., Prestwood K. M., Kenny A. M. Prevalence of sarcopenia and predictors of skeletal muscle mass in healthy, older men and women. J. Gerontol. A. Biol. Sci. Med. Sci., 2002, vol.57, no. 12, pp. M772-777. https://doi.org/10.1093/gerona/57.12.m772

30. Cruz-Jentoft A. J., Landi F., Schneider S. M., Zuniga C., Arai H., Boirie Y., Chen L-K., Fielding R.A., Martin F.C., Michel J.-P., Sieber C., Stout J.R., Studenski S.A., Vellas B., Woo J., Zamboni M., Cederholm T. Prevalence of and interventions for sarcopenia in ageing adults: a systematic review. Report of the International Sarcopenia Initiative (EWGSOP and IWGS). Age and Ageing, 2014, vol. 43, no. 6, pp. 748-759. https://doi.org/10.1093/ageing/afu115

31. Espinel-Bermúdez M.C., Ramírez-García E., García-Peña C., Salvà-Casanovas A., Ruiz-Arregui L., Cárdenas-Bahena A., Sánchez-García S. Prevalence of sarcopenia in community-dwelling older people of Mexico City using the EWGSOP (European Working Group on Sarcopenia in Older People) diagnostic criteria. J. Cachexia, Sarcopenia and Muscle, 2017, vol.2, no.2, pp.12-17. https://doi. org/10.17987/jcsm-cr.v2i2.9

32. Boland R. Role of vitamin D in skeletal muscle function. Endocr. Rev., 1986, vol. 7, no. 4, pp.434-448. https://doi.org/10.1210/edrv-7-4-434

33. Fougère B., Vellas B., van Kan G. A., Cesari M. Identification of biological markers for better characterization of older subjects with physical frailty and sarcopenia. Transl. Neurosci., 2015, vol. 6, no. 1, pp. 103-110. https://doi.org/10.1515/tnsci-2015-0009

34. Volpato S., Bianchi L., Cherubini A., Landi F., Maggio M., Savino E., Bandinelli S., Ceda G. P., Guralnik J.M., Zuliani G., Ferrucci L. Prevalence and clinical correlates of sarcopenia in communitydwelling older people: application of the EWGSOP definition and diagnostic algorithm. J. Gerontol. A. Biol. Sci. Med. Sci., 2014, vol. 69, no. 4, pp.438-446. https://doi.org/10.1093/gerona/glt149

35. Gariballa S., Alessa A. Sarcopenia: prevalence and prognostic significance in hospitalized patients. Clin Nutr., 2013, vol. 32, no. 5, pp. 772-776. https://doi.org/10.1016/j.clnu.2013.01.010

36. Houston D. K., Cesari M., Ferrucci L., Cherubini A., Maggio D., Bartali B., Johnson M.A., Schwartz G.G., Kritchevsky S.B. Association between vitamin D status and physical performance: 
the InCHIANTI study. Journals of Gerontology Series A: Biological Sciences and Medical Sciences, 2007, vol. 62, no. 4, pp. 440-446. https://doi.org/10.1093/gerona/62.4.440

37. Mastaglia S.R., Seijo M., Muzio D., Somoza J., Nunez M., Oliveri B. Effect of vitamin D nutritional status on muscle function and strength in healthy women aged over sixty-five years. Journal of Nutrition, Health and Aging, 2011, vol. 15, no. 5, pp. 349-354. https://doi.org/10.1007/s12603-010-0287-3

38. Rosendahl-Riise H., Spielau U., Ranhoff A.H., Gudbrandsen O.A., Dierkes J. Vitamin D supplementation and its influence on muscle strength and mobility in community-dwelling older persons: a systematic review and metaanalysis. J. Hum. Nutr. Diet., 2017, vol.30, no. 1, pp.3-15. https://doi. org/10.1111/jhn.12394

39. Visser M.D., Deeg D. J.H., Lips P. Low vitamin D and high parathyroid hormone levels as determinants of loss of muscle strength and muscle mass (sarcopenia): the Longitudinal Aging Study Amsterdam. Journal of Clinical Endocrinology and Metabolism, 2003, vol. 88, no. 12, pp.5766-5772. https:// doi.org/10.1210/jc.2003-030604

40. Bischoff-Ferrari H. A., Dietrich T., Orav E. J., Hu F. B., Zhang Y., Karlson E. W., Dawson-Hughes B. Higher 25-hydroxyvitamin D concentrations are associated with better lower-extremity function in both active and inactive persons aged $>$ or $=60$ y. Am. J. Clin. Nutr., 2004, vol. 80, no.3, pp. 752-758. https://doi.org/10.1093/ajcn/80.3.752

Received: October 16, 2018

Accepted: December 3, 2018

Author's information:

Yuliya A.Safonova — PhD, Associate Prof.; jula_safonova@mail.ru

Evgeny G.Zotkin — MD; ezotkin@mail.ru

Galina M.Glazunova — g-glazunova@mail.ru 